\title{
NOTE
}

\section{Ribotyping of Aeromonas salmonicida subsp. salmonicida}

\author{
B. Nielsen, J. E. Olsen, J. L. Larsen* \\ Department of Veterinary Microbiology, Royal Veterinary and Agricultural University, 13 Bulowsvej, DK-1870 Frederiksberg C., Denmark
}

\begin{abstract}
A collection of 124 strains of the bacterial fish pathogen Aeromonas salmonicida subsp. salmonicida isolated from diseased salmonids in Denmark $(n=57)$, Norway $(n=28)$, Scotland $(n=20)$, and North America $(n=19)$ was characterized by ribotyping. For reference, the type strain NCMB 1102 was likewise examined. Digestion of total DNA with the enzymes ECoR1, HindIII and Sma1 resulted in 2, 1 and 5 ribotypes, respectively, with a total of 6 ribotypes in combination. The type strain NCMB 1102 belonged to the most common of the ribotypes, irrespective of the enzyme used. Although Danish and North American strains were genetically very homogeneous, Norwegian and Scottish isolates showed some genetic diversity. In general, ribotyping was not found to be applicable as an epizootiological typing system for $A$. salmonicida subsp. salmonicida due to low discriminatory power. Norwegian and Scottish strains contained a common Sma1 ribotype suggesting a connection between isolates from these 2 countries.
\end{abstract}

KEY WORDS: Aeromonas salmonicida - Ribotyping - Genotyping

Furunculosis, caused by the fish pathogenic bacterium Aeromonas salmonicida, is one of the major diseases among farmed salmonids in both freshwater and seawater aquaculture. First isolated almost $100 \mathrm{yr}$ ago by Emmerich \& Weibel (1894), A. salmonicida is today found worldwide (Austin \& Austin 1987).

Phenotypic systems for subspecies characterization such as biotyping, serotyping, and resistotyping have been used within Aeromonas salmonicida without success because of the very homogeneous nature of the species (Austin \& Austin 1987). Phage typing has proved to be useful (Popoff 1971a, b, Rogers et al. 1981) but this system has not yet been applied to larger investigations on the epizootiology of furunculosis.

Genotypic methods such as plasmid profiling, restriction endonuclease analysis (RE), and ribotyping have proved to be effective tools for subspecies characterization of many pathogenic bacteria (Farrar 1983,

- Addressee for correspondence
Saunders 1991). In this report, results from ribotyping of strains of Aeromonas salmonicida subsp. salmonicida from Denmark, Norway, Scotland, and North America are presented with the aim of evaluating the possible use of this method as a tool for typing of A. salmonicida, and to elucidate the genetic variation within this bacterial subspecies.

Materials and methods. Bacterial strains and growth conditions: A collection of 124 strains of Aeromonas salmonicida subsp. salmonicida from Denmark, Norway, Scotland, and North America together with a reference strain, A. salmonicida subsp. salmonicida NCMB 1102, were investigated. The strains are listed in Table 1. All strains were isolated from diseased salmonids.

The bacteria were grown on brain heart infusion (BHI) agar (Difco, Detroit, MI, USA), After $48 \mathrm{~h}$ of incubation at $20^{\circ} \mathrm{C}, 5$ to 8 colonies were harvested, mixed in 1 Eppendorf tube, and used for DNA isolation.

Isolation of total DNA and ribotyping: Isolation of total DNA, quantification of DNA, and ribotyping were performed as previously described by Olsen et al. (1992). Briefly, $1 \mu \mathrm{g}$ of purified DNA was digested with one of the enzymes BamH1, Cla1, EcoR1, HindIII, Pst1, Sac1 or Sma1 (Boehringer, Mannheim), separated in $0.8 \%$ agarose gels (Litex, LSL), stained with $2 \mathrm{mg} \mathrm{l}^{-1}$ ethidium bromide (Sigma), and photographed under ultraviolet light. The DNA was transferred to nylonhybridization membranes (Hybond-N, Amersham) by vacuum blotting and hybridized with a digoxigenin (Boehringer, Mannheim) labelled DNA probe complementary to $16 \mathrm{~S}$ and 23S rRNA of Escherichia coli (Sigma).

Results. Choice of restriction enzymes for characterization: Total DNA of the reference strain NCMB 1102 was separately digested with the enzymes BamH1, Cla1, EcoR1, HindIII, Pst1, Sac1, and Sma1. When ribotyping was performed, the selected enzymes gave patterns with 7 to 9 clear bands and 2 to 5 weak 
Table 1. Source and year of isolation of the examined strains of Aeromonas salmonicida subsp. salmonicida from Denmark, Nurth America, Norway, and Scotland. Numbers refer to number of strains isolated

\begin{tabular}{|c|c|c|c|c|c|c|c|c|c|c|}
\hline \multirow[t]{2}{*}{ Host } & \multicolumn{10}{|c|}{ Year of isolation } \\
\hline & 1970 & 80 & 82 & 83 & 84 & 85 & 86 & 87 & 8889 & 90 \\
\hline \multicolumn{11}{|l|}{ Denmark ${ }^{a}$} \\
\hline Oncorhynchus mykiss & & & 8 & 7 & 8 & 8 & 4 & 4 & 2 & \\
\hline Salmo trutta & & & & 1 & 2 & 1 & 2 & 1 & 3 & \\
\hline Salvelinus fontinalis & & & & 2 & 1 & & & 1 & & \\
\hline Salmo salar & & & & 1 & & 1 & & & & \\
\hline \multicolumn{11}{|l|}{ North Americab } \\
\hline Salmo salar & & 1 & & & 1 & & 1 & & 1 & \\
\hline Salmo trutta & & & 1 & 1 & & & 1 & & & \\
\hline Salvelinus fontinalis & & & & & & 1 & & & 1 & \\
\hline Oncorhynchus mykiss & & & & & & 1 & & & 1 & \\
\hline Oncorhynchus ishawytscha & 1 & & & & & & $\hat{\imath}$ & & & \\
\hline \multicolumn{11}{|l|}{ Norwayc } \\
\hline Salmo salar & & & & & & & & & 24 & \\
\hline Oncorhynchus mykiss & & & & & & & & & 4 & \\
\hline \multicolumn{11}{|l|}{ Scotland ${ }^{d}$} \\
\hline Salmo salar & & & & & & & & & 20 & \\
\hline \multicolumn{11}{|c|}{$\begin{array}{l}\text { Strains provided by: }{ }^{a} \text { Dr I. Dalsgaard, Danish Institute for Fisheries and } \\
\text { Marine Research, Fish Disease Laboratory, Royal Veterinary and Agri- } \\
\text { cultural University, Copenhagen, Denmark; }{ }^{b} \mathrm{Dr} G \text {. Olivier, Dept of } \\
\text { Fisheries \& Oceans, Halifax, Canada; 'Dr E. Myhr, National Veterinary } \\
\text { Institute, Oslo, Norway; }{ }^{d} \text { Dr T. Hastings, The Scottish Office Agriculture } \\
\text { and Fisheries Dept, Marine Laboratory, Aberdeen, Scotland }\end{array}$} \\
\hline
\end{tabular}

bands (Fig. 1). With some of the enzymes (BamH1 and Pst1), the bands were very close to each other, while the bands were well separated with other enzymes (Cla1, EcoR1, HindIII, Sac1 and Sma1). Based on these results, the relatively inexpensive enzymes EcoR1, HindIII, and Sma1 were chosen for ribotyping of the full strain collection.

Ribotyping: Table 2 summarizes the results of the ribotyping. The enzyme HindIII gave 1 ribotype among all 124 strains examined, while EcoR 1 resulted in 2 different ribotypes (Fig. 2).

All strains from Denmark and Scotland, 23 strains from Norway (82\%), and 18 North American strains (95\%) belonged to EcoR1 ribotype no. 1, while 5 Norwegian strains $(18 \%)$ and 1 North American strain ( $5 \%$ ) belonged to EcoR1 ribotype no. 2.

As seen from Fig. 3, 5 different ribotypes were observed with the enzyme Sma1. All strains from Denmark and North America belonged to Sma1 ribotype No. 1. Norwegian strains could be divided into 2 Sma1 ribotypes, with 24 strains $(86 \%)$ in Sma1 ribotype no. 1 and 4 strains (14\%) in Smal ribotype no. 2. The 5 Norwegian strains of the EcoR1 ribotype no. 2 all belonged to Sma1 ribotype no. 1. The 20 Scottish strains could be divided into 5 Sma1 ribotypes. Six strains $(30 \%)$ belonged to Sma1 ribotype no. 1, 7 strains $(35 \%)$ to Sma1 ribotype no. 2 , 1 strain $(5 \%)$ to $S m a 1$ ribotype no. 3, 2 strains (10\%) to Sma1 ribotype no. 4 and 4 strains $(20 \%)$ to Sma1

Table 2. Ribotypes of 124 strains of Aeromonas salmonicida subsp. salmonicida. All strains had an identical HindIIl pattern. The table shows the Sma 1 distribution according to the observed EcoR1 type of the strains. The total number of different types was 6

\begin{tabular}{|lcrrrrrrr|}
\hline \multirow{2}{*}{ Enzyme: } & $\begin{array}{c}\text { EcoR1 } \\
\text { No. of strains } \\
\text { with type }\end{array}$ & \multicolumn{4}{c}{ No. of strains with type } \\
& 1 & 2 & 3 & 4 & 5 \\
\hline Denmark & $1:$ & 57 & 57 & 0 & 0 & 0 & 0 \\
\multirow{3}{*}{ Norway } & $2:$ & 0 & 0 & 0 & 0 & 0 & 0 \\
\multirow{3}{*}{ North America } & $1:$ & 23 & 19 & 4 & 0 & 0 & 0 \\
\multirow{5}{*}{ Scotland } & $2:$ & 5 & 5 & 0 & 0 & 0 & 0 \\
& 1. & 18 & 18 & 0 & 0 & 0 & 0 \\
& $2:$ & 1 & 1 & 0 & 0 & 0 & 0 \\
& $1:$ & 20 & 6 & 7 & 1 & 2 & 4 \\
& $2:$ & 0 & 0 & 0 & 0 & 0 & 0 \\
\hline
\end{tabular}

Fig. 1 Ribotypes of Aeromonas salmonicida subsp. salmonicida NCMB 1102 obtained after digestion with the enzymes (2) BamH1, (3) Cla1, (4) EcoR1, (5) HindIII, (6) Pst1, (7) Sac1 and (8) Sma1. Lane 1 represents the molecular weight marker with bands at $27,23,9.4,6.6,4.4,2.3$ and $2.2 \mathrm{~kb}$ 


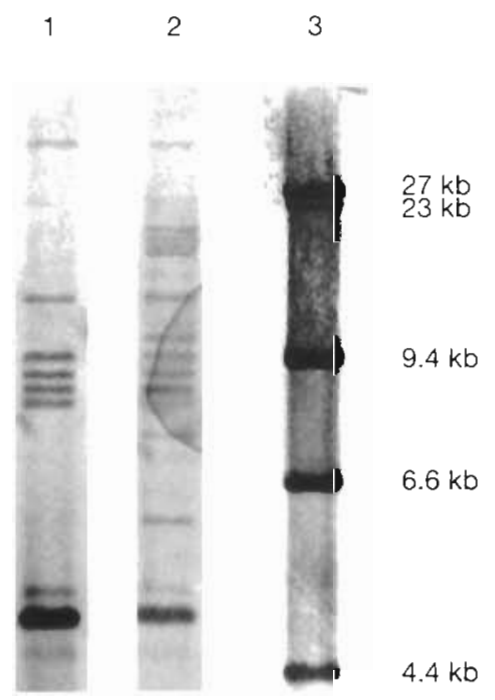

Fig. 2. ECoR1 ribotypes demonstrated among the 124 examined isolates of Aeromonas salmonicida subsp. salmonicida. Lane 1 demonstrates the common EcoR1 ribotype; Lane 2 demonstrates the rare EcoR1 ribotype. Molecular weight marker with bands at $27,23,9.4,6.6$, and $4.4 \mathrm{~kb}$ is shown in Lane 3

ribotype no. 5. Ribotypes were found to be reproducible on up to 8 repeating typings. No correlation with host species was demonstrated. The reference strain NCMB 1102 belonged to HindIII, EcoR1, and Sma1 ribotypes no. 1

Discussion. Ribotyping of the reference strain NCMB 1102 by use of 7 different enzymes showed that some enzymes were more suitable than others. In the ribotypes produced by Cla1, EcoR1, HindIII, Sac1, and Sma1 the bands were well separated and the ribotype was easily read. Based on this knowledge and the price of the enzymes, EcoR1 and HindIII were chosen for

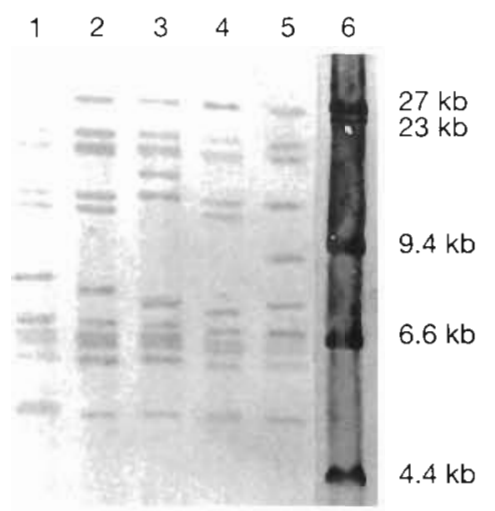

Fig. 3. Sma1 ribotypes demonstrated among the 125 examined strains of Aeromonas salmonicida subsp. salmonicida. Lanes 1 to 5 show the respective 5 Smal ribotypes; Lane 6 shows the molecular weight marker with bands at $27,23,9.4$, 6.6 and $4.4 \mathrm{~kb}$ ribotyping of the strain collection. The enzyme Sma1 was also chosen, as this enzyme has proved useful for ribotyping of other Gram-negative bacteria (Olsen et al. 1992).

A total of 6 ribotypes were detected in the present study. Two ribotypes were produced with EcoR1, but only $5 \%$ of the strains belonged to EcoR1 ribotype no. 2. In line with results published for ribotyping of Salmonella enteriditis (Martinetti \& Altwegg 1990) and S. berta (Olsen et al. 1992) ribotyping by use of Sma1 resulted in the highest degree of polymorphism. Danish and North American strains showed only 1 ribotype, and in general, Danish and North American strains of Aeromonas salmonicida subsp. salmonicida appeared to be very homogeneous as they, with the exception of 1 North American strain, produced only 1 ribotype after digestion with all 3 enzymes.

A higher degree of ribotype diversity was observed among strains originating from Norway and Scotland. The 20 Scottish strains, all isolated in 1990, resulted in 5 Sma1 ribotypes.

The plasmid content has previously been reported (Nielsen et al, 1993) and using plasmid profiling as a typing system, the Scottish strains showed a higher degree of variation than the Danish and North American ones.

The appearance of Sma1 ribotype no. 2 among both Scottish and Norwegian strains may indicate a link between these 2 countries. A similar indication has been noted by us using plasmid profiles as an epizootiological marker, e.g. a plasmid of $8.5 \mathrm{~kb}$ was detected only among Scottish and Norwegian strains (Nielsen et al. 1993). Other indications of links between geographically separated populations are indicated from the results. The appearance of EcoR 1 ribotype no. 2 in 5 strains from Norway and 1 strain from North America may indicate a connection, either directly or through a common third source. This relationship is possible because a large number of rainbow trout have been imported from North America to Europe (Austin \& Austin 1987).

In view of the observed distribution of ribotypes (Table 2), ribotyping, in general, must be considered of limited value and less useful than phage typing and plasmid profiling for epizootiological investigations of furunculosis outbreaks. However, the demonstration of 5 Sma1 ribotypes among 20 Scottish isolates shows that ribotyping in certain geographical areas may be useful. The demonstration of 5 Sma1 ribotypes among the 20 strains examined makes it seem likely that additional Smal ribotypes among Scottish Aeromonas salmonicida subsp. salmonicida strains will be demonstrated if a larger strain collection is examined. 
Acknowledgements. This study was supported by the Danish Agricultural and Veterinary Research Council no. 13-4244, and by the OECD Co-operative Research Project on Biological Resource Management. The skilled technical assistance of Sussi Kristoffersen is very much appreciated.

\section{LITERATURE CITED}

Austin, B., Austin, D. A. (1987). Bacterial fish pathogens: disease in farmed and wild fish. Ellis Horwood Ltd, Chichester

Emmerich, R., Weibel, E. (1894). Über eine durch Bakterien erzeugte Seuche unter den Forellen. Arch. Hyg. Bakteriol. 21: $1-21$

Farrar, W. E. J. (1983). Molecular analysis of plasmids in epidemiological investigation. J infect. Dis. 148: 1-6

Martinetti, G., Altwegg, M. (1990). rRNA gene restriction patterns and plasmid analysis as a tool for typing Salmonella enteritidis. Res. Microbiol. 141 1151-11h2.

Nielsen, B., Olsen, J. E., Larsen, J. L. (1993). Plasmid profiling

Responsible Subject Editor: T. Evelyn, Nanaimo, B.C., Canada within Aeromonas salmonicida as an epidemiological marker. Dis. aquat. Org. 15: 129-135

Olsen, J. E., Brown, D. J., Baggesen, D. L., Bisgaard, M. (1992). Biochemical and molecular characterization of Salmonella enterica serovar berta, and comparison of methods for typing. Epidemiol. Infect. 108: 243-260

Popoff, M. (1971a). Étude sur les Aeromonas sailmonicida. Ir. Caractérisation des bacteriophages actifs sur les Aeromonas salmonicida et lysotypie. Ann. Rech vet. 2: 35-45

Popoff, M. (1971b). Intérêt diagnostique d'un bactériophage spécifique des Aeromonas salmonicida. Ann. Rech. vet. 2: $137-139$

Rogers, C. J., Pringle, J. H., McCarthy, D. H., Austin, B. (1981). Quantitative and qualitative studies of Aeromonas salmonicida bacteriophage. J. gen. Microbiol. 125: 335-345

Saunders, N. A. (1991). Analysis of restriction fragment length polymorphisms in the study of bacteria. In: Grange, J. M., Morgan, N. L., Slanner, F. A. (eds.) Genetic manipulation. The Society for Applied Microbiology, Tech. Ser. Vol. 28. Blackwell Scientific Ltd, Oxford, p. 227-244

Manuscript first received: Octuver 5, 1992

Revised version accepted: November 10,1993 